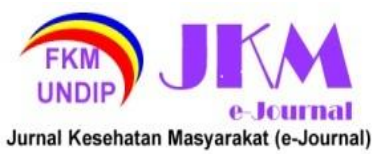

JURNAL KESEHATAN MASYARAKAT (e-Journal)

Volume 9, Nomor 5, September 2021

ISSN: 2715-5617 / e-ISSN: 2356-3346

http://ejournal3.undip.ac.id/index.php/jkm

\title{
FAKTOR-FAKTOR YANG MEMPENGARUHI PENGGUNAAN LAYANAN TELEMEDICINE PADA MASA PANDEMI COVID-19 DI PULAU JAWA
}

\author{
Maylin Djuana Siboro ${ }^{1^{*}}$, Antono Surjoputro ${ }^{2}$, Rani Tiyas Budiyanti ${ }^{2}$ \\ 1 Peminatan Administrasi dan Kebijakan Kesehatan, Fakultas Kesehatan Masyarakat Universitas \\ Diponegoro \\ 2 Bagian Administrasi dan Kebijakan Kesehatan, Fakultas Kesehatan Masyarakat Universitas \\ Diponegoro \\ ${ }^{*}$ Corresponding author : maylinsiboro@gmail.com
}

\begin{abstract}
ABSTRAK
The spread of COVID-19 in Indonesia has prompted the government to urge health agencies to develop telemedicine and direct people to minimize activities outside the home, including visiting health services. In its implementation, the use of telemedicine has increased rapidly even though it is still in the development stage and there is no specific regulation. Java Island as a region with a high number of COVID-19 cases has the potential to utilize telemedicine. The purpose of this study was to analyze the factors that influence the use of telemedicine during the COVID-19 pandemic on the island of Java. This research is a quantitative study with a cross-sectional approach. Respondents of the study were 269 people using the incidental sampling method. The results of this study indicate factors related to the use of telemedicine services during the Covid-19 period in Java, namely knowledge $(p=0.000)$, attitude $(p=0.000)$, trust $(p=0.000)$, accessibility $(p=0.000)$, role environment $(p=0.000)$, individual health assessment $(p=0.000)$, and perceived benefits $(p=0.006)$. Meanwhile, the unrelated factor was the perception of obstacles $(p=0.090)$. It is recommended that the government formulate telemedicine regulations related to patient protection guarantees, medical record safety, information and communication technology standards, and quality assurance. The health office conducts telemedicine education to the public and supervises telemedicine providers to ensure that services remain integrated with the health facilities.
\end{abstract}

Keywords : COVID-19, telemedicine, Java Island

\section{PENDAHULUAN}

Coronavirus merupakan jenis virus baru penyebab penyakit pada manusia yang ditemukan saat kejadian luar biasa di Wuhan Cina, pada Desember 2019. Virus ini kemudian kemudian dinamakan Severe Acute Respiratory Syndrome Coronavirus 2 (SARS-COV2) yang menyebabkan penyakit Coronavirus Disease2019 (COVID-19). ${ }^{1}$

Persebaran COVID-19 berkembang sangat cepat dengan adanya laporan kematian telah menimbulkan banyak negara ikut terjangkit, tidak terkecuali Indonesia. Berdasarkan bukti ilmiah, penularan COVID-19 dapat melalui droplet percikan batuk atau bersin dari seseorang kepada orang lainnya. Dengan demikian orang yang paling beresiko dapat tertular COVID-19 yaitu orang yang memiliki kontak langsung dengan pasien baik orang di sekitarnya maupun tenaga medis yang merawat pasien secara langsung. ${ }^{12}$

Pemerintah Indonesia merespon kondisi ini dengan meminta masyarakat untuk bekerja, belajar dan beribadah dari rumah. Pernyataan ini secara langsung menjelaskan agar masyarakat meminimalisir semaksimal mungkin untuk melakukan kegiatan di luar rumah termasuk untuk tidak mengunjungi pelayanan kesehatan kecuali dalam kondisi gawat darurat. ${ }^{3}$

Salah satu imbauan yang diberikan pemerintah kepada seluruh instansi kesehatan dan jajarannya yaitu pengembangan pelayanan jarak jauh (telemedicine) atau aplikasi online lainnya dalam memberikan pelayanan kepada pasien yang memerlukan. Hal ini ditunjukkan sebagai tanggungjawab pemerintah dalam penyelenggaraan layanan kesehatan di masa pandemi untuk meminimalkan risiko transmisi COVID-19.

Meskipun masih dalam proses pengembangan dan belum ada kepastian hukum secara spesifik yang mengatur penggunaan layanan telemedicine bagi masyarakat namun dalam keberjalanannya, implementasi layanan aplikasi telemedicine terus berjalan bahkan mengalami peningkatan penggunaan yang pesat di masa pandemi COVID-19. Salah satu platform telemedicine menyatakan bahwa layanannya telah dimanfaatkan lebih dari 20 juta pengguna di Indonesia selama kuartal II di tahun 2020. 


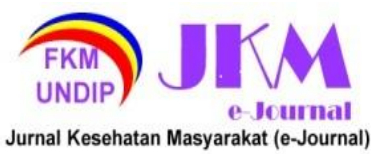

Secara umum pengguna layanannya mengalami peningkatan 10 kali lipat. ${ }^{4}$

Pulau Jawa menjadi daerah yang menyumbang lebih dari setengah kasus COVID19 nasional. 6 Selain itu, pulau Jawa juga memiliki pengguna internet tertinggi secara nasional dengan didukung oleh infrastrukur yang memadai dibandingkan daerah yang lainnya. ${ }^{7}$ Hal tersebut mendukung potensi masyarakat pulau Jawa untuk dapat mengakses pelayanan telemedicine.

Dengan adanya kondisi tersebut, maka perlu adanya penelitian terhadap masyarakat pengguna layanan ini terkait faktor-faktor yang mempengaruhi penggunaan layanan sehingga dapat memberikan gambaran mengenai fenomena / kejadian penggunaan layanan telemedicine di masa pandemi khususnya di pulau Jawa.

\section{METODE PENELITIAN}

Penelitian ini merupakan penelitian kuantitatif dengan pendekatan cross sectional. Penenelitian dilakukan di Pulau Jawa pada bulan November - Desember 2020 dengan jumlah responden sebanyak 269 orang.

Variabel bebas didalam penelitian ini terdiri dari pengetahuan, sikap, kepercayaan, aksesbilitas masyarakat, dukungan lingkungan sekitar, penilaian kesehatan individu, persepsi manfaat dan persepsi hambatan. Sedangkan variabel terikat didalam penelitian ini yaitu penggunaan layanan telemedicine di masa pandemi COVID-19.

Penentuan subjek penelitian menggunakan metode insidental sampling. ${ }^{8}$ Pengambilan sampel dilakukan dengan kriteria inklusi yaitu (1) Berdomisili di Pulau Jawa. (2) Berdomisili sementara di Pulau Jawa saat penggunaan layanan telemedicine. (3) Pernah menggunakan salah satu atau lebih layanan telemedicine dan bersedia menjadi responden.

Pengumpulan data melalui penyebaran kuesioner dalam bentuk google formulir dilakukan dengan memaksimalkan pemanfaatan media sosial dan fitur yang tersedia. Penyebaran kuesioner tidak hanya dilakukan oleh peneliti melainkan turut melibatkan para pengguna aktif sosial media lainnya. Penyebaran kuesioner ditujukan kepada setiap provinsi di Pulau Jawa. Namun, dikarenakan terdapat beberapa keterbatasan penelitian maka presentase responden dari setiap provinsi tidak $100 \%$ merata.

Sebelum digunakan, dilakukan uji reabilitas dan uji validitas instrumen penelitian kepada 30 responden yang tidak diikutsertakan dalam penelitian. Hasil uji menunjukkan data reliabel dan terdapat 2 pertanyaan yang tidak valid sehingga poin tersebut tidak diikutsertakan dalam instrumen penelitian.

\section{HASIL DAN PEMBAHASAN \\ Karakteristik Responden}

Tabel 1. Distribusi Frekuensi Karakteristik Responden

\begin{tabular}{clll}
\hline No. & \multicolumn{1}{c}{$\begin{array}{c}\text { Karakteristik } \\
\text { responden }\end{array}$} & $\mathbf{f}$ & $\%$ \\
\hline 1. & Usia & 28 & 10,4 \\
& $\leq 20$ tahun & 159 & 59,1 \\
& $21-30$ tahun & 42 & 15,6 \\
$31-40$ tahun & 40 & 14,9 \\
& $>40$ tahun & &
\end{tabular}

\section{Jenis Kelamin}

Perempuan $\quad 188 \quad 69,9$

Laki-laki 8130 ,

$\begin{array}{ll}\text { 3. Domisili } & \\ \text { Banten } & 23 \quad 8,6\end{array}$

DKI Jakarta $\quad 63 \quad 23,4$

Jawa Barat $\quad 10539,0$

Jawa Tengah $\quad 40 \quad 14,9$

DI Yogyakarta $19 \quad 7,1$

Jawa Timur $19 \quad 7,1$

\section{$\begin{array}{llll}\text { 4. } & \text { Pendidikan } & & \\ \text { Tamat SMP } & 5 & 1,9\end{array}$}

Tamat SMA $\quad 92 \quad 34,2$

Tamat Perguruan $\quad 172 \quad 63,9$ tinggi/Sederajat

$\begin{array}{lll}\text { 5. Pekerjaan } & & \\ \text { Tidak bekerja } & 20 & 7,4 \\ \text { Pelajar/Mahasiswa } & 85 & 31,6 \\ \text { PNS/TNI/Polri } & 17 & 6,3 \\ \text { Karyawan Swasta } & 102 & 37,9 \\ \text { Wiraswasta } & 11 & 4,1 \\ \text { Pekerjaan Lainnya } & 34 & 12,6\end{array}$

6. Jenis Telemedicine Halodoc $\quad 18949,1$

$\begin{array}{lll}\text { Alodokter } & 77 & 20\end{array}$

Klikdokter $\quad 16 \quad 4,2$

$\begin{array}{lll}\text { Mobile JKN } & 45 & 11,7\end{array}$

$\begin{array}{lll}\text { Sehatpedia } & 7 & 1,8\end{array}$

Konsultasi Dokter $\quad 6 \quad 1,6$

Dinas Kesehatan

Konsultasi Dokter $\quad 21 \quad 5,5$

Rumah Sakit

Konsultasi Dokter $\quad 14 \quad 3,6$

Puskesmas

Telemedicine lainnya $\quad 10 \quad 2,6$

Tabel 1 menunjukkan bahwa pada 269 responden sebagian besar berusia 21-30 tahun $(59,1 \%)$ dan lebih banyak ditemukan responden dengan jenis kelamin perempuan $(69,9 \%)$ dibandingkan laki-laki. Dari 6 provinsi yang ada 


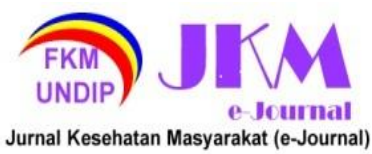

di Pulau Jawa, 39\% responden berdomisili di Jawa Barat, 23,4\% berdomisili di DKI Jakarta dan sisanya tersebar juga di 4 provinsi lainnya.

Berdasarkan tingkat pendidikan, mayoritas responden dalam penelitian ini tamat perguruan tinggi/sederajat (63,9\%). Dalam kategori pekerjaan, responden yang bekerja sebagai karyawan swasta merupakan jenis pekerjaan terbanyak 37,9\% dibandingkan yang lainnya.

Terdapat responden yang menggunakan lebih dari 1 jenis layanan. Total layanan yang pernah digunakan yaitu 385 layanan oleh 269 responden. Halodoc menjadi telemedicine terbanyak yang digunakan. Layanan ini digunakan oleh 189 responden $(49,1 \%)$.

\section{Penggunaan layanan telemedicine pada masa pandemi COVID-19}

Di Indonesia, telemedicine menjadi suatu inisiatif pemanfaatan teknologi informasi dan komunikasi untuk pelayanan dan informasi kesehatan yang ditujukan mengatasi masalah kesenjangan dan ketidakmerataan informasi dan pelayanan kesehatan. telemedicine pada mulanya diharapkan menjadi solusi untuk pemantauan status gizi, pemantauan status kesehatan masyarakat, dan bahkan konsultasi jarak jauh dengan petugas-petugas kesehatan yang memiliki kompeten yang cukup baik untuk masyarakat di daerah yang sulit dijangkau tanpa harus memikirkan jarak dan waktu. ${ }^{9}$ Seperti halnya yang tercantum pada Instruksi Presiden Republik Indonesia Nomor 9 Tahun 2017 tentang Percepatan Pembangunan Kesejahteraan di Provinsi Papua Dan Provinsi Papua Barat, pemanfaatkan teknologi komunikasi telemedicine juga diharapkan dapat menjadi pendukung percepatan peningkatan akses dan kualitas pelayanan kesehatan. ${ }^{10}$

Penyelenggaran telemedicine di Indonesia merujuk pada Peraturan Menteri Kesehatan No 20 tahun 2019 mengenai telemedicine antar fasilitas kesehatan. ${ }^{11}$ Namun, peraturan ini bukan ditunjukkan pada pelayanan dari satu fasilitas kesehatan kepada masyarakat/pasien.

Saat ini telemedicine telah direvitalisasi karena adanya pandemi COVID-19. Hal ini dilakukan sebagai bentuk tanggung jawab pemerintah untuk memenuhi kebutuhan masyarakat mengenai pelayanan kesehatan. Pemerintah menjadikan telemedicine sebagai salah satu alternatif model pelayanan kesehatan bagi yang membutuhkan. Hal ini di imbaukan kepada masyarakat dengan harapan dapat meminimalisir terjadinya kemungkinan penularan virus di fasilitas kesehatan dan memberikan perlindungan bagi tenaga kesehatan dan pekerja di layanan kesehatan lainnya.

Secara resmi Menteri Kesehatan dan Direktur Jenderal Pelayanan Kesehatan mengeluarkan Surat Edaran Nomor Hk.02.01/Menkes/303/2020 dan Surat Nomor YR.03.03/III/III8/2020 kepada seluruh Kepala Dinas Kesehatan, Kepala Instansi Kesehatan, dan Ogranisasi Profesi Kesehatan mengenai pengembangan telemedicine dan himbauan tidak melakukan praktik rutin kecuali emergensi. 12

Masyarakat merespon baik pemanfaatan telemedicine yang terlihat dari peningkatan jumlah pengguna yang sangat pesat dikarenakan banyaknya kebutuhan akan informasi dan pelayanan kesehatan terlebih di masa pandemi. Hasil penelitian menunjukkan bahwa sebagian besar penggunaan layanan telemedicine pada masa pandemi COVID-19 termasuk kedalam katergori sering dengan jumlah $55,8 \%$. Presentase tersebut lebih tinggi jika dibandingkan dengan pengguna yang termasuk kedalam kategori jarang dengan jumlah $44,2 \%$.

Hal ini disebabkan oleh frekuensi penggunaan telemedicine dan pilihan pelayanan yang digunakan oleh responden.

Dilihat dari frekuensi penggunaan, sebanyak $68 \%$ responden menyetujui bahwa dirinya menjadi lebih sering menggunakan layanan telemedicine di masa pandemi COVID19. Kondisi ini didukung dengan banyaknya jenis platform telemedicine yang tersedia termasuk Fasyankes seperti puskesmas dan rumah sakit yang mulai mengembangkan telemedicine-nya masing-masing. Sebanyak $35 \%$ responden pernah menggunakan 2 hingga 4 jenis platform telemedicine yang berbeda. Selain itu, dikarenakan terdapat beragam fitur yang tersedia dalam platform telemedicine, responden memanfaatkan pelayanan ini untuk berbagai kebutuhan kesehatan. Tidak hanya layanan konsultasi penyakit, melainkan menggunakan telemedicine untuk edukasi kesehatan sehari hari, peresepan online dan layanan lainnya.

Ketika diperhadapkan pada pilihan di masa pandemi COVID-19, sebagian besar responden pengguna telemedicine lebih memilih menggunakan layanan telemedicine terlebih dahulu dibandingkan layanan kesehatan konsultasi dokter bukan online $(77,7 \%)$. Kondisi ini didukung dengan adanya tantangan kondisi pandemi seperti semakin tertutupnya akses terhadap fasilitas kesehatan karena lebih memprioritaskan penanganan 


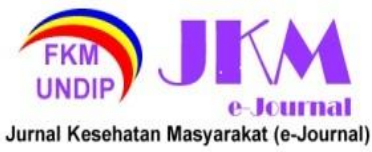

JURNAL KESEHATAN MASYARAKAT (e-Journal)

Volume 9, Nomor 5, September 2021

ISSN: 2715-5617 / e-ISSN: 2356-3346

http://ejournal3.undip.ac.id/index.php/jkm

permasalahan terkait COVID-19 dimana per harinya memiliki peningkatan jumlah kasus yang signifikan ${ }^{13}$

Tabel 2. Distribusi Frekuensi dan Hubungan Variabel Bebas dengan Variabel Terikat

\begin{tabular}{|c|c|c|c|c|c|}
\hline \multirow{3}{*}{ Variabel } & \multicolumn{4}{|c|}{ Penggunaan Telemedicine } & \multirow{3}{*}{ P-value } \\
\hline & \multicolumn{2}{|c|}{ Jarang } & \multicolumn{2}{|c|}{ Sering } & \\
\hline & $f$ & $\%$ & $\mathrm{f}$ & $\%$ & \\
\hline \multicolumn{6}{|l|}{ Pengetahuan } \\
\hline Kurang Baik & 70 & 61,9 & 43 & 38,1 & \multirow{2}{*}{0,000} \\
\hline Baik & 49 & 31,4 & 107 & 68,6 & \\
\hline \multicolumn{6}{|l|}{ Sikap } \\
\hline Negatif & & 70 & 24 & 29,6 & \multirow{2}{*}{0,000} \\
\hline Positif & & & & 67 & \\
\hline $\begin{array}{l}\text { Kepercayaan } \\
\text { Rendah }\end{array}$ & & & & & \multirow[b]{2}{*}{0,000} \\
\hline Tinggi & & & 101 & 66,9 & \\
\hline \multicolumn{6}{|l|}{ Aksesbilitas } \\
\hline $\begin{array}{l}\text { Rendah } \\
\text { Tingai }\end{array}$ & $\begin{array}{l}72 \\
47\end{array}$ & $\begin{array}{l}62,1 \\
307\end{array}$ & & $\begin{array}{l}37,9 \\
693\end{array}$ & 0,000 \\
\hline \multicolumn{6}{|l|}{ Peran Lingkungan Sekitar } \\
\hline Tidak Mendukung & 68 & 57,1 & 51 & & 0,000 \\
\hline \multicolumn{6}{|c|}{ Penilaian Kesehatan Individu } \\
\hline Rendah & 71 & 55,5 & 57 & 44,5 & \multirow{2}{*}{0,000} \\
\hline Tinggi . . . & 48 & 34 & 93 & & \\
\hline \multirow{2}{*}{\multicolumn{6}{|c|}{$\begin{array}{l}\text { Persepsi Manfaat } \\
\text { Rendah }\end{array}$}} \\
\hline & 67 & 53,2 & 59 & 46,8 & \multirow{3}{*}{0,006} \\
\hline Tinggi & 52 & 36,4 & 91 & 63,6 & \\
\hline Persepsi Hambatan & & & & & \\
\hline Rendah & & 37,2 & 59 & 62,8 & 0.090 \\
\hline Tinggi & 84 & 48 & 91 & 52 & \\
\hline
\end{tabular}

Tabel 2 menunjukkan variabel yang dianalisis terhadap penggunaan telemedicine di masa pandemi COVID-19 di Pulau Jawa.

Analisis hubungan antara pengetahuan, sikap, kepercayaan, aksesbilitas, peran lingkungan sekitar, penilaian kesehatan individu, persepsi manfaat dengan penggunaan layanan telemedicine.

1. Pengetahuan

Berdasarkan tabel 2 distribusi frekuensi penggunaan telemedicine, diketahui bahwa responden yang sering menggunakan layanan ditemukan pada kelompok yang memiliki pengetahuan baik $(68,6 \%)$. Sedangkan pengguna dengan kategori jarang lebih banyak ditemukan pada kelompok pengetahuan kurang baik $(61,9 \%)$. Berdasarkan hasil uji Chi-Square, diketahui terdapat adanya hubungan antara pengetahuan dengan penggunaan layanan telemedicine pada masa pandemi COVID19. Dengan demikian, semakin baik pengetahuan akan informasi mengenai penggunaan telemedicine maka semakin optimal seseorang dalam menggunakan layanan ini pada masa pandemi COVID-19.

Mayoritas pengguna telemedicine memiliki pengetahuan baik, tetapi perlu adanya pertimbangan mengenai informasi penting yang masih belum banyak diketahui masyarakat. Pada penelitian ini didapati $42,8 \%$ pengguna tidak mengetahui bahwa dokter memiliki tanggung jawab terhadap keamanan dan kerahasiaan data rekam medik pasien di layanan telemedicine. Peneliti melihat hal ini sejalan dengan edukasi yang belum maksimal dari pihakpihak yang terkait mengenai pentingnya masyarakat mengetahui adanya jaminan keamanan data rekam medik dalam layanan telemedicine yang digunakan. Dengan demikian masyarakat dapat memilih memanfaatkan pelayanan telemedicine yang terjamin dan memiliki reputasi baik.

2. Sikap

Berdasarkan tabel 2 diketahui bahwa responden yang sering menggunakan telemedicine lebih banyak ditemukan pada kelompok yang memiliki sikap positif $(67 \%)$. 


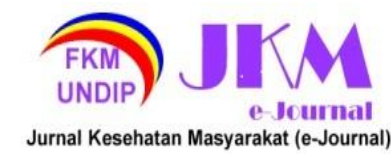

Sedangkan responden masuk dalam kategori jarang menggunakan layanan lebih banyak ditemukan memiliki sifat negatif (70,4\%).

Berdasarkan hasil uji statistik Chisquare yang dilakukan, didapatkan adanya hubungan antara sikap responden dengan penggunaan layanan telemedicine pada masa pandemi COVID-19. Dengan adanya hubungan tersebut menunjukkan bahwa semakin positif sikap seseorang terhadap sesuatu, maka semakin optimal seseorang menggunakan layanan ini pada masa pandemi COVID-19.

Variabel Sikap positif dalam penelitian ini sejalan dengan penelitian Cahyorini dari Puslitbang Upaya Kesehatan Masyarakat mengenai sikap hidup sehat masyarakat dalam menghadapi pandemi COVID-19 di Indonesia. Dimana $66,4 \%$ responden memiliki sikap sangat setuju bahwa melaksanakan himbauan di rumah saja merupakan cara terbaik untuk membatasi penularan Covid-19.14 Jika dikaitkan dengan penggunaan telemedicine yang merupakan alternatif pencegahan penularan Covid-19 di instansi kesehatan maka penggunaan telemedicine pun akan mendapat sikap postif dan menjadi sangat dipertimbangan oleh masyarakat yang membutuhkan layanan kesehatan dengan tetap mempertahankan diri di rumah.

3. Kepercayaan

Hasil tabulasi silang pada tabel 2 menunjukkan bahwa responden yang sering menggunakan telemedicine lebih banyak ditemukan pada kategori yang memiliki kepercayaan tinggi (66,9\%). Sedangkan responden masuk dalam kategori jarang memiliki kepercayaan yang rendah sebanyak 58,5\%. Hasil uji Chi-square menunjukkan adanya hubungan antara kepercayaan dengan penggunaan layanan telemedicine pada masa pandemi COVID19.

Sejalan dengan penelitian Rizky dan Debora, penggunaan telemedicine adalah salah satu bentuk kesepakatan antara dokter dengan pasien melalui sarana media elektronik. Adanya kepercayaan melalui cara online dapat terlihat dari penyampaian penyakit atau keluhan yang diderita, dan kemungkinan adanya pembayaran uang tertentu baik dalam bentuk transfer atau memotong dari pulsa pengguna telemedicine. Dengan demikian semakin seseorang sering menggunaan layanan telemedicine pada masa pandemi COVID-
19 dengan disertai penyampaian keluhan dan kemungkinan pengeluaran biaya tertentu yang perlu dikorbankan maka terlihat juga adanya kepercayaan yang tinggi pada layanan ini.

Meskipun demikian, masih terdapat presentase kepercayaan yang rendah. Hal ini disebabkan oleh: (1) mayoritas responden berpendapat bahwa telemedicine tidak dapat mengidentifikasi masalah kesehatan dengan lebih baik dibandingkan dengan kompetitor (konsultasi bukan online). Menurut penulis, masyarakat menjadi lebih mempertanyakan hasil dan kualitas diagnosa dikarenakan tidak adanya pemeriksaan fisik secara langsung serta jaminan perlindungan pasien jika terjadi kesalahan diagnosa. Apabila muncul malpraktik telemedicine, masyarakat akan semakin dirugikan karena belum adanya regulasi secara jelas mengenai siapa saja pihak yang akan bertanggung jawab. (2) Belum adanya jaminan keamanan data rekam medik. Dalam KODEKI pasal 16, telah diatur pertanggung jawaban kerahasiaan rekam medik oleh dokter. Namun, di dalam telemedicine yang melibatkan teknisi, platform penyedia layanan dan alat komunikasi maka perlu diperhatikan adanya kemungkinan data dapat diakses oleh peretas. (3) Kepercayaan akan kualifikasi telemedicine. Jika merujuk pada Perkonsil 74 tahun 2020 pasal 3 yang membahas bahwa dokter praktik telemedicine harus memiliki STR dan SIP dari Fasyankes serta pasal 9a mengenai larangan melakukan telekonsultasi tanpa melalui Fasyankes, maka perlu adanya jaminan bahwa setiap telemedicine sudah terintegrasi oleh Fasyankes.

4. Aksesbilitas

Hasil tabulasi silang pada tabel 2 antara penggunaan telemedicine dan aksesbilitas menunjukkan bahwa responden yang sering menggunakan layanan telemedicine memiliki aksesbilitas tinggi (69,3\%) sedangkan responden yang jarang menggunakan layanan telemedicine cenderung memiliki aksesbilitas rendah $(62,1 \%)$. Berdasarkan hasil uji Chi-square diperoleh hasil bahwa terdapat hubungan antara aksesbilitas dengan penggunaan layanan telemedicine pada masa pandemi COVID-19.

Penelitian ini sejalan dengan teori $\mathrm{L}$. Green dimana aksesbilitas termasuk dalam faktor pemungkin meliputi sarana prasarana 


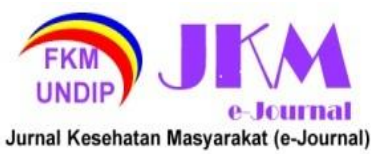

dan kemudahan yang ada untuk memungkinkan atau memfasilitasi perilaku atau tindakan kesehatan yang dilakukan responden. ${ }^{15}$ Dengan adanya hubungan tersebut menunjukkan bahwa semakin tinggi aksesbilitas seseorang terhadap layanan telemedicine, maka orang tersebut akan semakin optimal dalam penggunaan layanan telemedicine pada masa pandemi COVID-19.

5. Peran Lingkungan Sekitar

Berdasarkan hasil tabulasi silang pada tabel 2 diketahui bahwa responden yang sering menggunakan layanan telemedicine memiliki lingkungan sekitar yang mendukung $(66 \%)$. Sedangkan responden yang jarang menggunakan layanan telemedicine cenderung memiliki lingkungan yang tidak mendukung $(57,1 \%)$. Hasil uji statistik Chi-square menunjukkan bahwa terdapat hubungan signifikan antara peran lingkungan sekitar dengan penggunaan layanan telemedicine pada masa pandemi COVID-19. Hal tersebut dibuktikan dengan nilai $p$-value $=0,000(p$ value $<0,05$ ).

Diketahui bahwa lingkungan sekitar yang paling berperan mempengarui responden dalam menggunakan telemedicine berasal dari teman/kerabat. Jika dibandingkan dari sisi petugas kesehatan, sebagian besar responden menilai petugas kesehatan masih kurang mendukung dalam menyarankan penggunaan layanan telemedicine $(51,3 \%)$. Penulis menilai pihak instansi kesehatan belum memaksimalkan sosialisasi telemedicine karena masih memprioritaskan pelayanan kesehatan secara langsung dengan salah satu pertimbangan layanan telemedicine yang tersedia masih dalam tahap pengembangan.

6. Penilaian Kesehatan Individu

Hasil tabulasi silang di tabel 2 antara penggunaan telemedicine dan penilaian kesehatan individu menunjukkan bahwa responden yang sering menggunakan layanan telemedicine memiliki penilaian kesehatan individu yang tinggi (66\%). Sedangkan responden yang jarang menggunakan layanan telemedicine banyak ditemukan memiliki penilaian kesehatan individu rendah (44,5\%). Hasil secara statistika dengan uji Chi-square menunjukkan bahwa terdapat hubungan antara penilaian kesehatan individu dengan penggunaan layanan telemedicine pada masa pandemi COVID-19.
Penelitian ini sejalan dengan penelitian Manurung, adanya penilaian kesehatan yang tinggi atau penilaian terhadap derajat penyakit yang semakin dirasakan berat, maka individu tersebut akan semakin membutuhkan kesembuhan yang memerlukan adanya pelayanan kesehatan. Perlunya kebutuhan akan suatu layanan kesehatan maka akan menimbulkan semakin tinggi pula keinginan untuk memanfaatkan pelayanan kesehatan tersebut. ${ }^{16}$

Penelitian ini juga sejalan dengan teori Andersen yang menyatakan bahwa pemanfaatan layanan kesehatan dipengaruhi oleh kebutuhan terhadap pelayanan kesehatan. Dimana kebutuhan tersebut ditentukan salah satunya oleh penilaian kesehatan individu. Sehingga dapat diartikan bahwa semakin tinggi penilaian kesehatan individu maka semakin optimal seseorang memanfaatkan pelayanan telemedicine pada masa pandemi COVID-19.

7. Persepsi Manfaat

Persepsi manfaat mengenai telemedicine yang dimaksudkan meliputi: 1) Dapat mendeteksi kemungkinan masalah kesehatan. 2) Memungkinkan penyembuhan masalah kesehatan menjadi lebih besar. 3) Biaya yang terjangkau. 4) kemudahan penggunaan platform/aplikasi. 5) Syarat mendaftar layanan tidak banyak. 6) Fleksibel perihal waktu penggunaannya. 7) Dapat digunakan sebagai alternatif layanan kesehatan selama masa pandemi.

Berdasarkan hasil tabulasi silang di tabel 2 antara penggunaan telemedicine dan persepsi manfaat terdapat hasil bahwa mayoritas responden yang sering menggunakan layanan telemedicine memiliki persepsi manfaat yang tinggi $(63,6 \%)$. Hasil uji statistik Chi-square menunjukkan nilai $p$-value persepsi manfaat $=0,006(p<0,05)$ yang berarti terdapat hubungan antara persepsi manfaat dengan penggunaan layanan telemedicine pada masa pandemi COVID-19.

Penelitian ini sejalan dengan teori Health Belief Model yang menyatakan bahwa persepsi manfaat merupakan salah satu faktor kepercayaan individu yang mempengaruhi seseoarang untuk mengambil keputusan kesehatan. ${ }^{17}$ Dengan adanya hubungan tersebut menunjukkan bahwa semakin tinggi persepsi manfaat seseorang terhadap layanan telemedicine, maka orang tersebut akan semakin optimal 


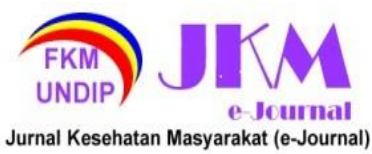

dalam penggunaan layanan telemedicine pada masa pandemi COVID-19.

\section{Analisis hubungan antara persepsi hambatan dengan penggunaan layanan telemedicine}

1. Persepsi Hambatan

Hasil tabulasi silang di tabel 2 antara penggunaan telemedicine dan persepsi hambatan menunjukkan bahwa responden yang sering menggunakan layanan telemedicine memiliki persepsi hambatan rendah (62,8\%). Sedangkan responden yang jarang menggunakan layanan telemedicine banyak ditemukan memiliki persepsi hambatan tinggi (48\%). Persepsi hambatan yang paling tinggi menurut sebagian besar responden yaitu kurangnya keamanan data dan rekam medik layanan telemedicine.

Hasil uji statistik Chi-square menunjukkan nilai $p$-value persepsi hambatan $=0,090$. $(p>0,05)$ yang berarti tidak terdapat hubungan antara persepsi hambatan dengan penggunaan layanan telemedicine pada masa pandemi COVID19.

Menurut teori Health Belief Model persepsi ancaman dari suatu masalah kesehatan atau penyakit dapat membuat seseorang enggan untuk mengadopsi suatu keputusan, tetapi terdapat juga pengaruh dari persepsi manfaat yang bisa didapatkan jika mengadopsi suatu keputusan tersebut apakah perilaku tersebut dapat mengurangi ancaman penyakit atau masalah.

Dalam penelitian ini ditemukan bahwa tidak terdapat hubungan antara persepsi hambatan dengan penggunaan layanan telemedicine pada masa pandemi COVID19 yang menunjukkan penelitian tidak sesuai dengan teori Health Belief Model. Terjadinya hal ini disebabkan oleh hambatan yang dirasakan responden tidak sampai menghentikan responden dalam penggunaan telemedicine Dengan demikian, dapat juga disimpulkan bahwa persepsi manfaat yang dialami responden lebih besar dibandingkan persepsi hambatan

\section{KESIMPULAN}

Berdasarkan 7 faktor yang ada, terdapat 6 faktor yang memiliki hubungan dengan penggunaan layanan telemedicine di masa pandemi COVID-19 di pulau Jawa yaitu pengetahuan, sikap, kepercayaan, aksesbilitas, peran lingkungan sekitar, penilaian kesehatan individu, dan persepsi manfaat sedangkan faktor yang tidak memiliki hubungan yaitu persepsi hambatan.

\section{SARAN}

Adapun saran yang diberikan peneliti yaitu: 1) Kementerian Kesehatan menyusun regulasi telemedicine terkait jaminan perlindungan pasien, keamanan rekam medik, standar teknologi informasi dan komunikasi, dan jaminan mutu. 2) Dinas Kesehatan dan Ikatan Profesi Kesehatan meningkatkan edukasi kepada masyarakat mengenai penggunaan telemedicine serta melakukan monitoring kepada penyelenggara telemedicine untuk menjamin pelayanan tetap terintegrasi dengan Fasyankes. 3) Penyelenggara Layanan telemedicine seperti Fasyankes dan start-up melakukan pengembangan layanan secara berkelanjutan sesuai kebutuhan kesehatan masyarakat.

\section{DAFTAR PUSTAKA}

1. Kementerian Kesehatan RI. Pedoman Pencegahan dan Pengendalian Corona Virus Deases (Covid-19) Revisi Ke-5. Kementrian Kesehat. 2020;

2. Sekretariat Kabinet Republik Indonesia | WHO Tetapkan Covid-19 Pandemi, Dirjen P2P: Semua Negara Harus Antisipasi dan Respons [Internet]. 2020. Available from: https://setkab.go.id/whotetapkan-covid-19-pandemi-dirjen-p2psemua-negara-harus-antisipasi-danrespons/

3. Sekretariat Kabinet Republik Indonesia Minta Masyarakat Tenang, Presiden: Saatnya Bekerja, Belajar, dan Beribadah dari Rumah [Internet]. Available from: https://setkab.go.id/minta-masyarakattenang-presiden-saatnya-bekerjabelajar-dan-beribadah-dari-rumah/

4. Layanan Dokter Spesialis Telemedicine Jadi Incaran Selama Pandemi - Startup Katadata.co.id [Internet]. Available from: https://katadata.co.id/agungjatmiko/digit al/5f088475842b3/layanan-dokterspesialis-telemedicine-jadi-incaranselama-pandemi

5. Aplikasi Kesehatan Good Doctor dan Halodoc Buat Program Atasi Corona Startup Katadata.co.id [Internet]. Available from: https://katadata.co.id/desysetyowati/digit al/5e9a421409504/aplikasi-kesehatangood-doctor-dan-halodoc-buat-programatasi-corona

6. Lidwina A. Lebih dari $50 \%$ Kasus Covid- 


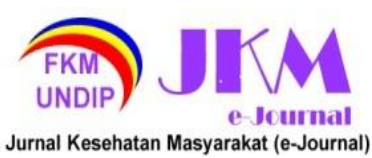

19 Nasional Berasal dari Pulau Jawa [Internet]. Databoks. Available from: https://databoks.katadata.co.id/datapubli sh/2020/09/01/lebih-dari-50-kasuscovid-19-nasional-berasal-dari-pulaujawa

7. Kementrian Komunikasi dan Informatika. Penggunaan Internet di Indonesia Ditjen Aptika [Internet]. Available from: https://aptika.kominfo.go.id/2019/08/pen ggunaan-internet-di-indonesia/

8. Sugiono. Metode Penelitian Administrasi. Alfabeta; 2009.

9. Pasaribu KF, Arisjulyanto $\mathrm{D}$, Hikmatushaliha BT. Pengembangan Telemedicine dalam Mengatasi Konektivitas dan Aksesibilitas Pelayanan Kesehatan. Ber Kedokt Masy. 2018;

10. Kementereian Sekretariat Negara Republik Indonesia. Instruksi Presiden Nomor 9 Tahun 2017 Tentang Percepatan Pembangunan Kesejahteraan Di Provinsi Papua dan Provinsi Papua Barat. 2017.

11. Menteri Kesehatan Republik Indonesia. Peraturan Menteri Kesehatan No. 20 tahun tentang Penyelenggaraan Pelayanan Telemedicine antar Fasilitas Pelayanan Kesehatan. 2019 p. 1-15.

12. Kementerian Kesehatan Republik
Indonesia. Surat Edaran No. HK.02.01MENKES-303-2020 tentang Pelayanan Kesehatan Melalui Teknologi Informasi Dalam Pencegahan COVID-19. 2020.

13. Masyarakat Beralih ke Telemedis, Menkominfo Sebut Pandemi Covid-19 Percepat Transformasi Digital [Internet]. Available from: https://nasional.kompas.com/read/2020/ 08/22/12212511/masyarakat-beralih-ketelemedis-menkominfo-sebut-pandemicovid-19-percepat

14. Cahyorini, ST M. Pengetahuan, Sikap, Dan Perilaku Hidup Sehat Masyarakat Dalam Menghadapi Pandemi Covid-19 Di Indonesia. J Chem Inf Model. 2020;34-5.

15. Notoatmodjo S. Promosi Kesehatan dan Perilaku Kesehatan. Jakarta: Rineka Cipta; 2012. 138-150 p.

16. Manurung A. Hubungan Perceived dan Evaluated Need Perawatan Karies Gigi dengan Pemanfaatan Pelayanan Kesehatan Gigi Pada Masyarakat di Kota Pematang Siantar. 2008;

17. Mckenna SP. Predicting health behaviour: Research and practice with social cognition models. Saf Sci. 1996;24(3):229-30. 